\title{
An Amazonian fruit with a high potential as a natural source of vitamin C: the camu-camu (Myrciaria dubia)
}

Roberta B. Rodrigues ${ }^{a}$, Hilary C. De Menezes ${ }^{a}$, Lourdes M.C. Cabral ${ }^{b}$, Manuel Dornier ${ }^{c, d \star}$, Max Reynes ${ }^{c, d}$

a University of Campinas, Food Technology Dept. (FEA / Unicamp),

Cidade Universitária

Zeferino Vaz,

C.P. 6121 ,

13083-970 Campinas,

S.P., Brazil

b Embrapa,

Agroindustria de Alimentos,

Av. das Américas,

29501 Guaratiba,

23020-470 Rio de Janeiro,

Brazil

${ }^{\mathrm{c}}$ Centre de coopération internationale en recherche agronomique

pour le développement,

Cirad-flhor,

Av. Agropolis, TA 50/PS4,

34398 Montpellier Cedex 5,

France

d École nationale supérieure des Industries alimentaires, Tropical Food Dept. (Ensia-Siarc),

BP 5098 ,

34033 Montpellier Cedex 1, France

dornier@cirad.fr

* Correspondence and reprints

Received 5 January 2001 Accepted 4 April 2001

Fruits, 2001, vol. 56, p. 345-354 (c) 2001 Cirad/EDP Sciences All rights reserved

Resumen Español, p. 354

\section{An Amazonian fruit with a high potential as a natural source of vitamin C: the camu-camu (Myrciaria dubia).}

Abstract - The plant. The camu-camu [Myrciaria dubia (H.B.K.) Mc. Vaugh] is a shrub from the Myrtaceae family. It grows naturally in floodable and swampy areas of the Amazonian basin. This plant is cultivated in Peru and Brazil with fruit yields ranging from (12 to 20) $t$ $\times$ ha $^{-1} \times$ year $^{-1}$. The fruit. The fruit, from $(1$ to 3$) \mathrm{cm}$ in diameter, is pink to dark purple; it is the highest known source of natural vitamin $\mathrm{C}$, providing $(850$ to 5,000$) \mathrm{mg} \times 100 \mathrm{~g}^{-1}$ edible portion. The market. In the last few years, both national and international demand for the camu-camu fruit has drastically increased for the production of health food or of natural vitamin C. The current fruit production is not sufficient to satisfy the market. Conclusion. M. dubia stands out amongst other Amazonian fruit species as having a high economic and social potential. Little information is available on its processing, showing the need for research in this area.

Amazonia / Brazil / Peru / Myrciaria dubia / taxonomy / botany / geographical distribution / cultivation / chemical composition / ascorbic acid / markets / processing

\section{Un fruit amazonien à fort potentiel en tant que source naturelle de vitamine $\mathrm{C}$ : le camu-camu (Myrciaria dubia).}

Résumé - La plante. Le camu-camu [Myrciaria dubia (H.B.K.) Mc. Vaugh] appartient à la famille des myrtacées. Cet arbuste pousse naturellement dans les zones inondables et marécageuses du bassin amazonien. Il est actuellement cultivé au Pérou et au Brésil avec des rendements compris entre (12 et 20) $\mathrm{t} \times \mathrm{ha}^{-1} \times \mathrm{an}^{-1}$. Le fruit. Le fruit du camu-camu est une baie de couleur rose à violet et de 1 à $3 \mathrm{~cm}$ de diamètre ; il présente des teneurs en vitamine $\mathrm{C}$ extrêmement élevées, comprises entre (850 et 5000) mg $\times 100 \mathrm{~g}^{-1}$ de partie comestible. Le marché. La demande internationale pour le camu-camu a considérablement augmenté au cours de ces dernières années. Le fruit est essentiellement utilisé comme source naturelle de vitamine $\mathrm{C}$ et pour la formulation d'aliments diététiques. Néanmoins, la production ne parvient pas à faire face à la demande. Conclusion. Parmi les fruits secondaires amazoniens, le camu-camu présente un potentiel socio-économique considérable. L'étude de voies de transformation du fruit respectueuses de sa qualité nutritionnelle est aujourd'hui nécessaire.

Amazonie / Brésil / Pérou / Myrciaria dubia / taxonomie / botanique / distribution geographique / pratique culturale / composition chimique / acide ascorbique / marché / traitement 


\section{Introduction}

The Amazon basin is this planet's richest source of natural resources, both concerning its extensive fauna, with more than 3,000 species of fish, and its flora. It occupies areas in six countries (Bolivia, Brazil, Columbia, Ecuador, Peru and Venezuela) and represents a fifth of the world availability of fresh water and one third of its available latifoliate forests. In Brazil, the Amazon spreads through the following states: Pará, Amazonas, Maranhão, Goiás, Mato Grosso, Acre, Amapá, Rondonia and Roraima. The region presents a great number of exotic fruit trees in the wild state, with a small number being explored for agricultural purposes. Of these, one which stands out is the camu-camu, Myrciaria dubia (H.B.K.) Mc Vaugh, growing wild in areas subject to periodic inundation, which makes it economically important to the region because such areas are generally considered inadequate for other cultivation [1].

Interest in this fruit and its cultivation has been growing both in Brazil and in Peru since the camu-camu a high source of vita$\min \mathrm{C}$, presenting a total amount often more than $2 \mathrm{~g} \times 100 \mathrm{~g}^{-1}$ in the whole pulp. The juice of the fruit is an excellent alternative for increasing the value of the raw material by industrial transformation. It is a natural product with a high vitamin $\mathrm{C}$ content, which can be used as a soft drink or in the production of jams, nectars, ice cream, liquor, yoghurt, etc.

\section{Table I.}

Taxonomic position of camu-camu [2, 3].

$\begin{array}{lc}\text { Division } & \text { Fanerogamas } \\ \text { Sub-division } & \text { Angiospermas } \\ \text { Class } & \text { Dicotiledoneas } \\ \text { Sub class } & \text { Rosidae } \\ \text { Order } & \text { Myrtales } \\ \text { Sub order } & \text { Myrtanae } \\ \text { Family } & \text { Myrtaceae } \\ \text { Genus } & \text { Myrciaria } \\ \text { Species } & \text { Myrciaria dubia (H.B.K.) McVaugh }\end{array}$

However, it is interesting to note that new studies are underway aimed at improving the quality/yield of the fruit production (improvements to the soil and plants, identification of species), at adapting the plant to firm land - thus increasing possible plantation areas and regions - and also to applying technological knowledge to obtain a variety of products, making the fruit viable for consumption in regions where it is not cultivated.

This paper aims to summarize the knowledge concerning the camu-camu fruit cultivation, commercialization and industrialization. Some information is presented about the agronomic aspects, fruit composition, production costs, market and processing.

\section{Plant description}

\subsection{Taxonomy}

Identified in 1958 by Mc Vaugh, the camucamu, Myrciaria dubia (H.B.K.) McVaugh (table I), is also known as Eugenia divaricata Benth., M. phillyracoides Berg., M. divaricata (Benth.), M. riedeliana Berg., M. caurensis Steyerm, M. paraensis Berg., M. spruceana Berg. and Psidium dubium H.B.K [2, 3-5].

Since the camu-camu is found in extensive areas in distinct countries, it is also designated by a variety of other common names such as camo-camo in Peru, Caçari and Araçá d'água in Brazil, Guayabo in Columbia and Guayabato or Guayabito in Venezuela [3, 5].

Currently, two types of camu-camu are recognized with very similar fruit but distinct vegetative forms such that they do not belong to the same species since one is a shrub and the other a tree, known as M. dubia and Myrciaria sp., respectively, (table II) [6].

\subsection{Botany}

The camu-camu shrub (M. dubia) is approximately $8 \mathrm{~m}$ in height, rarely reaching $12 \mathrm{~m}$, glabrous with a smooth trunk which may 
Table II.

Differentiating characteristics between Myrciaria dubia and Myrciaria sp. [6].

\begin{tabular}{lcc}
\hline Characteristic & Myrciaria dubia & Myrciaria sp. \\
\hline Plant type & Shrub & Tree \\
Harvesting period & December - May & March - May \\
Weight of fruit & $(10$ to 20$) \mathrm{g}$ & $(23$ to 40$) \mathrm{g}$ \\
Fruit color & Dark red to purple & Purple to brown \\
Fruit skin & Parchment like & Semi-woody \\
Seed color & Yellowish & Pinkish \\
Seed size & Large & Small \\
Seed shape & Flat, kidney-shaped & Oval, hard \\
Number seeds / fruit & 1 to 3 & 1 to 2
\end{tabular}

reach $15 \mathrm{~cm}$ in diameter. Its color ranges from light brown to purple, with bark which peels off naturally in periods of drought [2-7]. The shrub is deeply rooted and the roots have a great number of absorbing hairs. The leaves are opposed, single, petiolar, elliptical or lanceolate, (3 to 10$) \mathrm{cm}$ in length and (1.5 to 4.5$) \mathrm{cm}$ in width, with an acuminated apex and rounded base, provided with a central vein with (18 to 20) pairs of lateral veins, and cylindrical petiole with a length of (3 to 6) $\mathrm{mm}$ and width of (1 to 2 ) $\mathrm{mm}$ (figure 1) [2, 4, 6].

Flowering is axial, with generally four subsessile hermaphrodite flowers arranged in two pairs, rounded ciliated bracts and white tiny perfumed petals [2, 3-6]. These flowers have about 125 stamens of ( 6 to 10) $\mathrm{mm}$ long.

The fruit is globular, from (1.0 to 3.2$) \mathrm{cm}$ in diameter, thin shiny skin going from pink to deep red or even dark purple when completely ripe, with juicy, extremely acid, pink pulp. It contains one to four kidney-shaped seeds per fruit - most commonly three from ( 8 to 15 ) $\mathrm{mm}$ in length and (5.5 to 11) $\mathrm{mm}$ in width [2-8].

The greatest source of genetic diversity is in the Peruvian Amazon where natural plantations exist. There, the germoplasm collection indicates at least 29 species of natural shrub camu-camu populations and ten tree camu-camu species $[5,6]$. The variability between populations, which may be genetic or due to climatic factors, can be observed at the time of fructification. The studies on variability and genetic improvement have been carried out by the Instituto Nacional de Investigaciones Agricolas (INIA) in Peru, the National Institute of Amazon Research (INPA) and the Brazilian Agricultural Research Corporation (EMBRAPA) in Brazil. The characteristics most evaluated in the experiments are the productivity per plant and, on a smaller scale, the ascorbic acid production.

\subsection{Origin and geographical distribution}

The camu-camu plant can be found throughout almost the whole of the Amazon

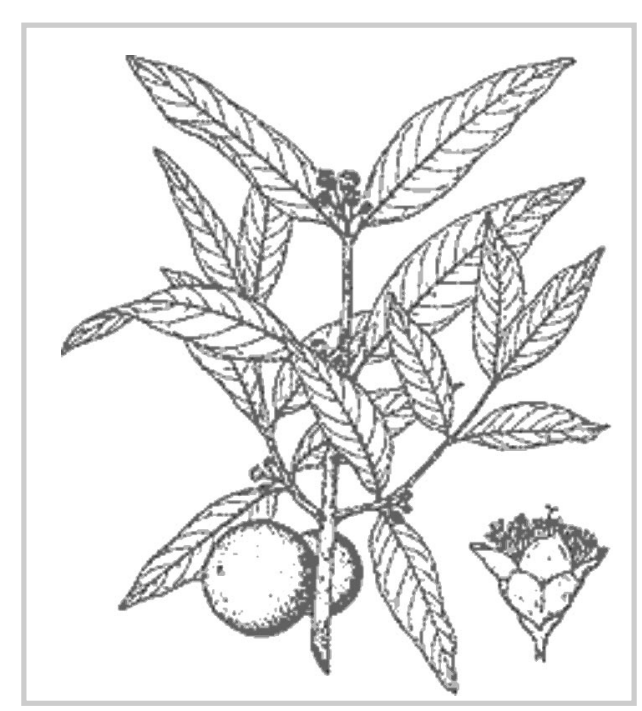

Figure 1.

Leaves, flowers and fruits of camu-camu (Myrciaria dubia). 


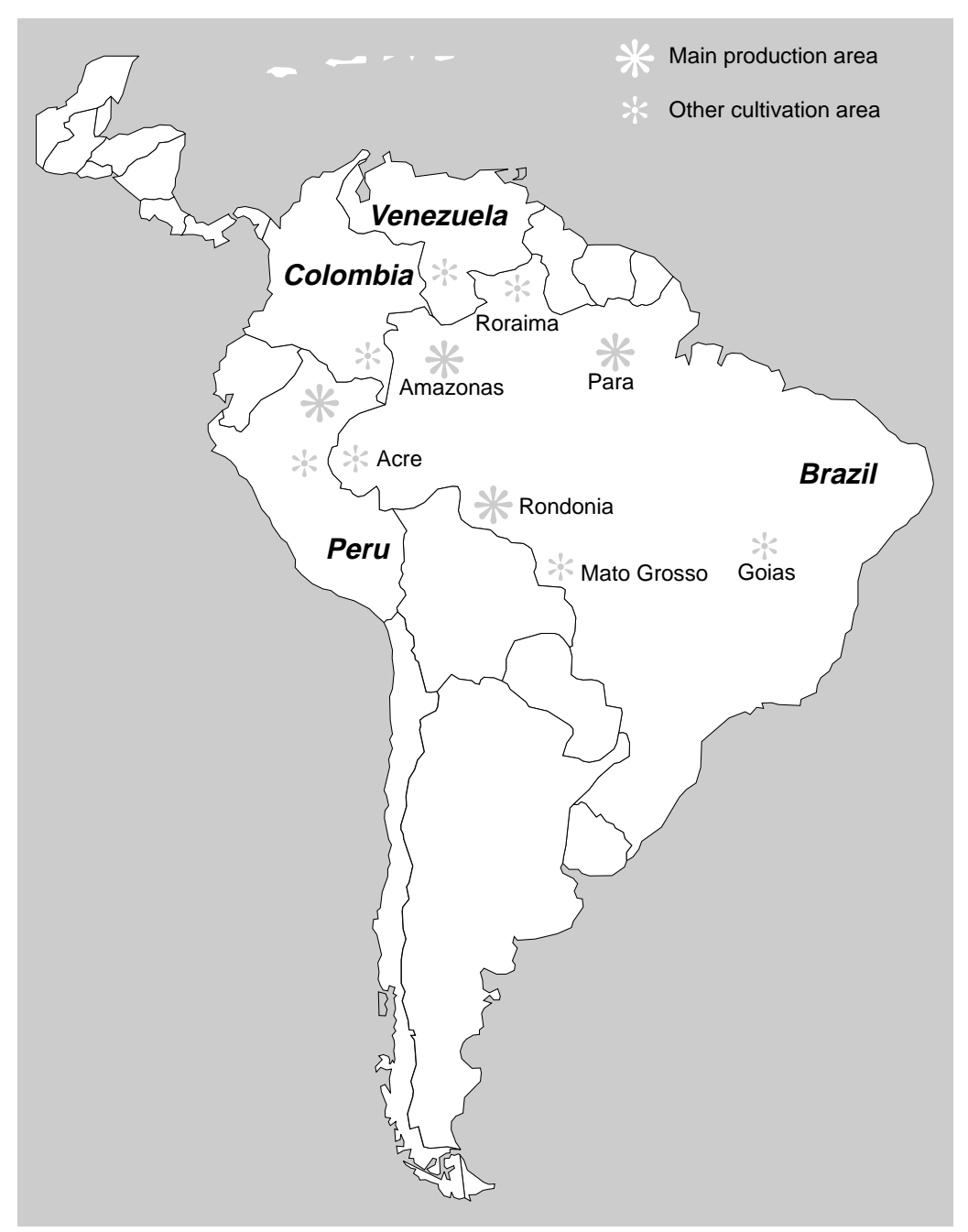

Figure 2.

Distribution of camu-camu in South-America. region, growing naturally on the banks of rivers, streams, lakes and swamps (figure 2 ). The greatest concentration of natural populations and varieties can be found in the Peruvian Amazon, mainly along the Ucayali and Amazon rivers and their tributaries [5]. In Brazil, its distribution extends into the states of Pará, along the river Trombetas, Cachorro and Mapuera; the state of Rondonia, along the river Javari and its tributaries, Maçangana and Upurá, and passing through the middle and upper Amazon and upper Solimões rivers. Its distribution also extends into Venezuela, in the upper and middle Orenoco basin and into Columbia $[2,3,5]$. In the sixties, the camu-camu was also introduced into the state of Florida in the USA [3].

\section{Agronomic aspects}

\subsection{Conditions for cultivation}

Native of the Amazon, the camu-camu develops naturally in periodically flooded areas of high humidity. Tolerant of flooding, this species can remain completely submersed for approximately 5 months [2, $3,5,6]$.

The camu-camu is a tropical plant which can be adapted to hot sub-tropical climates since it develops rapidly in temperatures oscillating between (20 and 35$){ }^{\circ} \mathrm{C}, 30{ }^{\circ} \mathrm{C}$ being considered ideal since this is the mean temperature in its natural habitat [2].

In zones where the camu-camu grows wild, the average rainfall is between (2500 and 3000) $\mathrm{mm} \times$ year $^{-1}$, and, when cultivated, the plant develops well with average rainfalls varying from (1700 to 3500 ) $\mathrm{mm}$ $\times$ year $^{-1}$, although, in areas where the rainfall is $1700 \mathrm{~mm} \times$ year $^{-1}$, there must be excessive drainage and a short dry period $[2,5,6]$.

In the wild state, the camu-camu develops in alluvial substrates, with a muddy, clay-like, gritty texture and in only lightly drained soils [3]. According to a study carried out at the Universidad Nacional de la Amazonia Peruana (UNAP), in regions where camu-camu grows wild in Peru, the soil has a $\mathrm{pH}$ varying between 4.5 and 6.5 $[2,6]$.

Various studies have already been carried out with the objective of evaluating the performance of the cultivated camu-camu. Silva et al. [7] evaluated the performance of camu-camu on firm land around Manaus (Amazonas, Brazil). In 1980, INPA put the camu-camu on its list of priorities, also aiming at its cultivation on firm land. In Peru, the Pucallpa zone is the region where the camu-camu is most cultivated. The plant has been cultivated in alluvial floodable soils, in non-floodable soils with deficient drainage and in well drained soils. It has been observed that its adaptation to all these conditions is satisfactory. It was shown that the amounts of water on the surface of the soil and in the soil, both 
directly influenced flowering and, hence, fructification $[5,9,10]$.

\subsection{Propagation and pests}

Traditionally camu-camu is propagated from seeds, which show $90 \%$ viability when recently separated from the fruit. The seeds used as rootstock are obtained from ripe fruit with a violet color, collected in alluvial floodable areas. The fruit must be harvested in a hygienic way from selected adult plants producing more than $15 \mathrm{~kg} \times$ year $^{-1}[5,6]$. The seeds are separated from the fruit either by squeezing or opening it with the fingers, and the part of the pulp adhering to the seed is removed using water. Then, the seeds are placed in a well-ventilated and shady area for $1 \mathrm{~h}$ to remove the excess of water before being classified according to size and broken seeds eliminated. This preparation must be done in a single day quickly, since the seeds rapidly lose their germination power $[5,6]$.

Before seeding, the seeds must be pregerminated. Two methods are used: stratification in moist sawdust or the empouching method.

The moist stratification method is carried out in (5 to 10) L containers, placing an approximately $5 \mathrm{~cm}$ deep layer of moist sawdust at the bottom. A layer of seeds is then placed on top of the sawdust such that all are in contact with the sawdust and $1 \mathrm{~cm}$ distant from the walls of the container. The seeds are then covered with a $3 \mathrm{~cm}$ layer of moist sawdust and the operation repeated until the container is full. The container is then stored in a well-ventilated place which is easy to water. Germination starts from (20 to 25) d after stratification, and the seeds are then either removed to the seed beds or one waits until the plants have ten pairs of leaves and are $10 \mathrm{~cm}$ in length before planting them in the seed beds, where they formed homogeneous batches. Uneven seed beds are recommended because this allows moisture retention after each rainfall or watering. The seedlings are planted with $10 \mathrm{~cm}$ between rows and $10 \mathrm{~cm}$ between plants. The plants grow to $70 \mathrm{~cm}$ in height in (6 to 8) months, after which they can be used for grafting.
In the empouching method, the seeds are placed in transparent polyethylene pouches where they germinate after $20 \mathrm{~d}$. This method has the advantage of being much simpler than the stratification one, slightly faster and it allows working with a greater volume of seeds. The only disadvantage is that the seeds must be removed before the roots reach $3 \mathrm{~cm}[5,6]$.

For grafting, the plants are placed with $60 \mathrm{~cm}$ between the rows and $40 \mathrm{~cm}$ between plants. They are ready for grafting 4 months after transplanting. After grafting, they should remain in the same bed for (6 to 8) months until the shape pruning has been carried out; then, the plants are ready for planting in their final destination. Fragment grafting is used. Shoots are chosen from plants selected for their high fruit productivity $\left(>25 \mathrm{~kg} \times\right.$ plant $^{-1} \times$ year $\left.^{-1}\right)$ [6].

Certain possible pests attacking M. dubia were recorded and described with the damage caused and the possibility of controlling them (table III) $[2,5,6]$.

\subsection{Flowering and fructification}

When the plants reach $2 \mathrm{~cm}$ in basal diameter, they initiate their flowering in the distal part of the highest branches and extend it to the lower branches. Thus, buds, flowers and fruit in various stages of development can simultaneously be observed $[3,5]$. Flowering is directly related to the hydrologic flow, that is, natural flowering occurs when the water level goes down, such that the branches and leaves are exposed to the sun. This normally occurs from September to November [3] and thus fructification occurs between December and March. When cultivated in firm land, the camu-camu flowers throughout almost the whole year, peaking in the dry season up to the beginning of the rainy season [9].

Although some pollination occurs by the wind, the most frequent pollinators are small bees attracted by the nectar and the sweet fragrance of the flowers. In general, $46 \%$ of the flowers are pollinated and an average of $15 \%$ of the immature fruits aborted before reaching maturity [3]. 


\section{Table III.}

Main pests, damage and control on camu-camu [2, 5, 6].

\begin{tabular}{|c|c|c|c|}
\hline Pest & Description & Damage & Control \\
\hline Aphis gossypii & $\begin{array}{l}\text { Homoptera, Aphididae } \\
\text { Pale yellow-dark green }\end{array}$ & $\begin{array}{l}\text { Desiccation of shoots } \\
\text { and leaves }\end{array}$ & $\begin{array}{l}\text { Natural adequate } \\
\text { beneficial insects }\end{array}$ \\
\hline $\begin{array}{l}\text { Austrotachardiella } \\
\text { sexcordata }\end{array}$ & $\begin{array}{l}\text { Homoptera, Kerriidae } \\
\text { Brown star shape }\end{array}$ & $\begin{array}{l}\text { Total or partial } \\
\text { desiccation of branches }\end{array}$ & $\begin{array}{l}\text { Cut and destroy } \\
\text { affected branches }\end{array}$ \\
\hline $\begin{array}{l}\text { Ceroplastes } \\
\text { flosculoides }\end{array}$ & $\begin{array}{l}\text { Homoptera, Coccidae } \\
\text { Golden }\end{array}$ & $\begin{array}{l}\text { Kills badly infected } \\
\text { shrubs }\end{array}$ & $\begin{array}{l}\text { Natural parasites and predators } \\
\text { Frequent visual control }\end{array}$ \\
\hline Conotrachelus dubiae & $\begin{array}{l}\text { Curculionid } \\
\text { Dark brown covered } \\
\text { by light brown scales }\end{array}$ & $\begin{array}{l}\text { Darkening of fruit } \\
\text { to brown }\end{array}$ & $\begin{array}{l}\text { Anticipate the harvest } \\
\text { and remove affected fruit }\end{array}$ \\
\hline Dysmicoccus brevipes & $\begin{array}{l}\text { Homoptera, Pseudococcidae } \\
\text { Females covered by white } \\
\text { waxy secretion }\end{array}$ & $\begin{array}{l}\text { Produce necrosis, } \\
\text { disappearance of bark } \\
\text { and tree death }\end{array}$ & Combat ants \\
\hline Ecthoea quadricornis & $\begin{array}{l}\text { Coleoptera } \\
\text { Greeny grey with two dark patches }\end{array}$ & $\begin{array}{l}\text { Females cut the branches } \\
\text { after laying eggs (branches } \\
\text { contaminated with larvae) }\end{array}$ & $\begin{array}{l}\text { Destroy affected } \\
\text { branches found on soil }\end{array}$ \\
\hline Laemosaccus sp. & $\begin{array}{l}\text { Curculionid } \\
\text { Black, brown feet }\end{array}$ & Desiccation of branches & $\begin{array}{l}\text { Cut and destroy } \\
\text { affected branches }\end{array}$ \\
\hline Parasaissetia nigra & $\begin{array}{l}\text { Homoptera } \\
\text { Yellow when young, } \\
\text { becoming purplish brown }\end{array}$ & $\begin{array}{l}\text { Induce reduction } \\
\text { of photosynthesis }\end{array}$ & $\begin{array}{l}\text { Natural avispita parasites } \\
\text { Chemical not justified }\end{array}$ \\
\hline Tuthillia cognata & $\begin{array}{l}\text { Homoptera, Psyllidae } \\
\text { Light brown }\end{array}$ & $\begin{array}{l}\text { Deform young leaves } \\
\text { limiting growth of shoots }\end{array}$ & $\begin{array}{l}\text { Natural: inefficient } \\
\text { Chemical: needs to be studied }\end{array}$ \\
\hline Xylosandrus compactus & $\begin{array}{l}\text { Scolytidae } \\
\text { Female: shiny and dark } \\
\text { Male: light brown }\end{array}$ & $\begin{array}{l}\text { Leaves dry out and stalks } \\
\text { and branches die }\end{array}$ & $\begin{array}{l}\text { Burn and destroy } \\
\text { the plants as soon as discover } \\
\text { first symptoms }\end{array}$ \\
\hline Apioscelis bulbosa & Orthoptera, Proscopidae & Feed on leaves & - \\
\hline Edessa sp. & $\begin{array}{l}\text { Pentatomidae } \\
\text { Green }\end{array}$ & Dries out shoots & - \\
\hline
\end{tabular}

\subsection{Harvest}

The wild populations and those planted in floodable regions are harvested between December and March whilst those cultivated in non-floodable land have a longer harvesting period, between November and May.

In the non-floodable regions, harvesting is carried out manually, once or twice per week, according to the stage of production. In the natural plantations, harvesting is carried out from canoes since the land is cov- ered by water, only collecting the fruit above the surface [5]. In these populations, harvesting is repeated every (4 to 5 ) $d$ at peak periods and every $8 \mathrm{~d}$ the rest of the year [6].

The fruit is harvested at the beginning of ripening when the previously green skin acquires some wine colored patches. After (3 to 4) d, the fruit acquires an intense wine color. If the fruit is to be used for the production of vitamin $\mathrm{C}$, harvesting should be done when the fruit is still completely green, although at its maximum size. 
The yields of fruit from natural and cultivated populations are directly correlated with the stage of maturity of the plant determined from the diameter of the trunk. However, a plant with a $12 \mathrm{~cm}$ trunk (mature) produces approximately $30 \mathrm{~kg} \times$ year $^{-1}$. With 625 plants $\times \mathrm{ha}^{-1}$, the production is approximately $18.5 \mathrm{t} \times \mathrm{ha}^{-1} \times$ year $^{-1}$. The camu-camu yield in Peru is estimated between (11.7 and 20.8) $\mathrm{t} \times \mathrm{ha}^{-1} \times$ year $^{-1}$, considering a plantation in its maximum development. For small cultivation with small resources, the yield can decrease to $12 \mathrm{t} \times \mathrm{ha}^{-1} \times$ year $^{-1}[5]$.

\section{The fruit}

\subsection{Composition}

The main components of the camu-camu pulp were identified by Villachica $[5,6]$ (table IV). This work highlighted high content of vitamin $\mathrm{C}$ in that fruit, which was confirmed by other authors.

Zapata and Dufour [11], analyzing camucamu juice, found values ranged from (845 to 939$) \mathrm{mg}$ vitamin $\mathrm{C} \times 100 \mathrm{~g}^{-1}$ juice for unripe, semi-ripe and ripe fruit, whereas Villachica [5] found range values between (1700 to 2700) $\mathrm{mg}$ vitamin $\mathrm{C} \times 100 \mathrm{~g}^{-1}$ for the green, semi-ripe, ripe and overripe fruit. The maximum value for ascorbic acid was found in the semi-ripe fruit, that is, between $50 \%$ and $75 \%$ ripe. Other studies on fruit ripening showed that, $56 \mathrm{~d}$ after anthesis, the camu-camu had a content of $2005 \mathrm{mg}$ ascorbic acid $\times 100 \mathrm{~g}^{-1}$; this value decreased to $1613 \mathrm{mg}$ ascorbic acid $\times 100 \mathrm{~g}^{-1}, 71 \mathrm{~d}$ after anthesis, although it then increased again, reaching a maximum value of $2606 \mathrm{mg}$ ascorbic acid $\times 100 \mathrm{~g}^{-1}, 113 \mathrm{~d}$ after anthesis $[3,12]$. These studies showed that the maximum vitamin $\mathrm{C}$ production was thus in the ripe fruit, demonstrating that, today, there is discordance about the peak of vitamin $\mathrm{C}$ production during ripening.

Compared to other tropical fruits, camucamu is the richest source of vitamin $C$ (table V) [5, 13, 14], however, the method used in the determination of the ascorbic acid content may be a factor contributing to the different values presented.
Franco and Shimabamoto studied the composition of volatiles of some Brazilian fruits, including camu-camu [15]. Twenty one aroma compounds were found in this

\section{Table IV.}

Average composition of camu-camu pulp $[5,6]$.

\begin{tabular}{lc} 
Component & Value per $100 \mathrm{~g}$ of pulp \\
\hline Total soluble solids & $7.7 \mathrm{~g}$ \\
Energy & $7.1 \mathrm{~kJ}$ \\
Protein & $0.5 \mathrm{~g}$ \\
Carbohydrate & $4.7 \mathrm{~g}$ \\
Fibre & $0.6 \mathrm{~g}$ \\
Ash & $0.2 \mathrm{~g}$ \\
Calcium & $27.0 \mathrm{mg}$ \\
Phosphorus & $17.0 \mathrm{mg}$ \\
Iron & $0.5 \mathrm{mg}$ \\
Thiamine & $0.01 \mathrm{mg}$ \\
Riboflavin & $0.04 \mathrm{mg}$ \\
Niacin & $0.062 \mathrm{mg}$ \\
Ascorbic acid & $2780 \mathrm{mg}$ \\
Vitamin C & $2994 \mathrm{mg}$ \\
&
\end{tabular}

Table V.

Vitamin C content of some tropical and sub-tropical fruits $[5,13,14]$.

$\begin{array}{lc}\text { Fruit } & \text { Vitamin C }\left(\mathrm{mg} \times 100 \mathrm{~g}^{-1}\right) \\ \text { Banana } & 9 \\ \text { Pineapple } & 15 \\ \text { Custard apple } & 20 \\ \text { Passion fruit } & 22 \text { to } 30 \\ \text { Mango } & 28 \\ \text { Feijoa } & 29 \\ \text { Tangerine } & 31 \\ \text { Grapefruit } & 34 \\ \text { Lemon } & 44 \\ \text { Persimmon } & 40 \text { to } 66 \\ \text { Papaya } & 62 \\ \text { Orange } & 37 \text { to } 92 \\ \text { Lychee } & 72 \\ \text { Longan } & 84 \\ \text { Kiwifruit } & 98 \text { to } 180 \\ \text { Jujube } & 500 \\ \text { Guava } & 11 \text { to } 980 \\ \text { West Indian cherry } & 680 \text { to } 4680 \\ \text { Camu-camu } & 850 \text { to } 5000\end{array}$


identification, $\alpha$-pinen and D-limonen being those present in greatest abundance in the head space, occupying $66 \%$ and $24 \%$, respectively, of the total peak areas.

\subsection{Production costs and market}

There has been some talk of production costs but at the Peruvian level, since, in Peru, the cultivation, industrialization and commercialization are at a more advanced level than in Brazil. According to Villachica [5], the production cost of the fruit is about US $\$ 0.50 \times \mathrm{kg}^{-1}$ with the current rate of production. With increases in the area of plantation, this value could go down to US\$ $0.43 \times \mathrm{kg}^{-1}$. Today, in Brazil, frozen fruits can be bought directly from the producer for US\$ $1.0 \times \mathrm{kg}^{-1}$, this including the costs of freezing and isothermal container for transport. On the market of Rio de Janeiro (CEASA's central food distribution centre), commercialization of the frozen pulp is still very limited, and the price is approximately US\$ $2.5 \times \mathrm{kg}^{-1}$.

The fruit is mainly consumed in the area where it is cultivated. In the biggest Brazilian commercial centers such as Rio de Janeiro and São Paulo, it is possible to find the fruitjuice in some special market places, which costs around US\$ 3,0 $\times \mathrm{L}^{-1}$.

In Peru, until 1998, camu-camu production was approximately $8 \mathrm{t} \times$ year $^{-1}$ [16] However, with the governmental and the private enterprises incentive, production could set up $1000 \mathrm{t}$ at the end of 2000 . The international demand for camu-camu is drastically increasing, in particular from the Japanese market - fifth fruitimporter of the world - and from the USA and European markets. In 1998, this demand was 20,000 t and it is currently estimated at 230,000 $\mathrm{t} \times$ year $^{-1}$ or, approximately, US\$ $450 \times 10^{6} \times$ year $^{-1}$.

According to the world demand and the present Peruvian production, it will be necessary to plan implementation of camu-camu cultivation, to obtain 8,000 ha (US\$ $64 \times 10^{6}$ ) for export.

Brazil does not have official data about production of camu-camu. Research is mainly about genetic improvement and adaptation from the plant in non-flood soil. In this country the fruit is mainly consumed in the areas where it is cultivated.

\subsection{Processing}

Camu-camu fruit is used for the manufacture of juices, ice-creams, concentrates, nectars, and for the production of natural vitamin C. It is never consumed in natura due to its very high acidity $[2,4,8,17,18]$. One of the main uses of the pulp is in the preparation called 'healthy beverages', using the refined pulp, which is the main product obtained from the fruit. Thus, it is necessary to invest in technology not only to improve production but to allow the use of the fruit as beverages or other products for regions where it is not cultivated.

The yield of refined pulp is low, from $50 \%$ to $55 \%$, seeds and skin representing $38 \%$ to $40 \%$ of the fruit in weight $[5,19]$.

The main works about camu-camu fruit have been about cultivation, diseases and pests. There are few studies about the fruit processing and industrialization due to the difficulty of obtaining the raw material.

Rodrigues et al. optimized the extraction of camu-camu pulp [19]. Three extractors were tested: a brush depulper, a blade depulper and a finisher. The ascorbic acid content, yield, peroxydase activity and sensorial quality were determined in the obtained pulps. It was observed that the brush depulper provided the greatest pulp yield but also the greatest loss in ascorbic acid. Concerning the peroxydase activity, the brush depulper produced the juice with a little more peroxydase activity probably due to some damage of the seeds. The sensory evaluation showed no difference in acceptance from the brush depulper and the blade depulper, but a great rejection was observed when the pulp was obtained from the finisher. The brush depulper was finally selected as the best technological way according to the sensory evaluation and the pulp yield.

Campos developed a pasteurization optimization study of camu-camu pulp [20]. An experimental factorial design $2^{2}$ was done, using time of (1.3 to 3.0) $\mathrm{min}$ and 
temperature of (73 to 90 ) ${ }^{\circ} \mathrm{C}$ as independent variables. According to ascorbic acid content and microbiological quality, the optimum found was $80{ }^{\circ} \mathrm{C}$ and (1.3 to 2) $\min$.

Rodrigues etal. worked with clarification of camu-camu juice using crossflow microfiltration after enzymatic treatment [21]. The experiments were conducted with tubular and plate membranes of an average pore diameter between $(0.1$ and 0.3$) \mu \mathrm{m}$. With permeate flux from (29 to 43) $\mathrm{L} \times \mathrm{h}^{-1} \times \mathrm{m}^{-2}$, the ascorbic acid loss was less than $1 \%$. In all the cases, the microbiological quality of the permeate was very good and its turbidity was reduced by $60 \%$ to $65 \%$. It was concluded that this process was effective for clarifying and sterilizing the camu-camu juice without decreasing the vitamin $\mathrm{C}$ content.

\section{Conclusion}

Camu-camu could be a new raw material to be explored in the Amazonian region or other areas in which it can be cultivated. However, it is necessary to carry out more research aimed at the improvement of the productivity and the quality of the fruit itself. New technologies for the industrial processing of the fruit but preserving its nutritional quality must be applied to allow the development of the commercialization of the camu-camu in the national and international markets.

\section{References}

[1] Silva S., Tassara H., Frutas do Brasil, Empresa das Artes, São Paulo, 1996.

[2] Alvarado Vertiz M.A., Posibilidades del cultivo del camu-camu en el Peru Myrciaria dubia, Monografia graduação, Pontificia Univ. Catolica del Peru, Lima, 1969.

[3] Andrade J.S., Curvas de maturação e características nutricionais do camu-camu [Myrciaria dubia (H.B.K.) Mc. Vaugh] cultivado em Terra firme da Amazônia Central, Ph.D. thesis, Univ. Campinas, Fac. Food Eng., Brazil, 1991.
[4] Ferreyra H.R., El camu-camu nueva fuente natural de vitamina $\mathrm{C}$, Bol. Exp. Agropecuaria (Lima) 7 (1959) 28-31.

[5] Villachica L.H., El cultivo del camu-camu Myrciaria dubia (H.B.K.) Mc. Vaugh en la Amazônia Peruana, Tratado de Cooperacion Amazonica, Lima, Peru, 1996.

[6] Villachica L.H., Frutales y hortalizas promisórios de la Amazônia, Proyecto FAO/GCP/ RLA/118/NET, Lima, Peru, 1996.

[7] Silva S.E.L., De Souza A. das G.C., Avaliação do desempenho do camu-camu [Myrciaria dubia (H.B.K.) Mc. Vaugh] em terra firme na região de Manaus, AM, EmbrapaCPAA, Manaus, Brazil, 1996.

[8] Ferreira F.R., Ferreira S.A.N., Carvalho F.E.U., Especies frutiferas pouco exploradas com potential economico e social para o Brasil, Rev. Bras. Frutic. 9 (1987) 11-12.

[9] Falcão M.A., Ferreira S.A.N., Chávez F., Clement C.R., Aspectos fenológicos e ecológicos de camu-camu [Myrciaria dubia (H.B.K.) Mc Vaugh] na terra firme da Amazônia central, in: Anais Congresso Brasileiro de Fruticultura, Fortaleza, Ceará, Brasil, 10, 1989, pp. 59-64,

[10] Clay J.W., Clement C.R., Selected species and strategies to enhance income generation from Amazonian forest, Forestry working paper, FAO, Roma, Italy, 1993.

[11] Zapata S.M, Dufour J.B., Camu-Camu Myrciaria dubia (H.B.K.) Mc. Vaugh: chemical composition of fruit, J. Sci. Food Agric. 61 (1993) 349-351.

[12] Andrade J.S., Aragão C.G., Galeazzi M.A.M., Ferreira S.A.N., Changes in concentration of total vitamin $\mathrm{C}$ during maturation and ripening of camu-camu [Myrciaria dubia (H.B.K) Mc. Vaugh] fruits cultivated in the upland of Brasil (Central Amazon), Acta Hortic. 370 (1995) 177-180.

[13] Gomez P., Reynes M., Dornier M., Hébert J.P., La cerise des Antilles : une exceptionnelle source de vitamine $C$ naturelle, Fruits 54 (1999) 247-260.

[14] Anonymous, Natural food-fruit vitamin C content, The Natural Food Hub, http://naturalhub.com/natural_food_guide_fruit_vitamin_c.htm, UHIS, 2000.

[15] Franco M.R., Shimabamoto T., Volatiles composition of some Brazilian fruits: umbu-caja (Sondias citherea), camu-camu (Myrciaria dubia), araça-boi (Eugenia stipitata) and cupuaçu (Theobroma grandiflorum), J. Agric. Food Chem. 48 (2000) 1263-1265. 
[16] Anonymous, El camu camu, fuente de vitamina C, Organización de Estados Iberoamericanos para la Educación, la Ciencia y la Cultura, Servicio Informativo Iberoamericano, Mayo 1999 (2), Brazil, http://www.oei.org.co/ sii/entrega15/art06.htm.

[17] Calzada Benza J., 143 frutales nativos, Librería El Estudiante, Lima, Peru, 1980.

[18] Clement C.R., Food and fruit-bearing forest species. 3: examples from Latin America, FAO Forest. Paper (Roma) 44 (1986) 201-203.

[19] Rodrigues R.B., Dib Taxi C.M., Campos F.P., Menezes H.C., Whole camu-camu (Myrciaria dubia) juice: extraction, optimisation and sensory evaluation, $10^{\text {th }}$ World Cong. Food
Sci. Technol., Sydney, Australia, 3-8 October 1999.

[20] Campos F.P., Otimização da extração e avaliação da vida de prateleira do suco integral de camu-camu (Myrciaria dubia), Relatório final do projeto de iniciação científica desenvolvido com apoio financeiro, Fapesp, Brazil, 1999.

[21] Rodrigues R.B., Cabral L.M.C., Menezes de H.C., Estudo do processo de microfiltração na clarificação e esterilização a frio de suco de camu-camu, XVII Congresso Brasileiro de Ciência e Tecnologia de Alimentos, Univ. federal do Ceará, Fortaleza, Brasil, vol. 2, 2000.

\section{Una fruta amazónica con gran potencial como fuente natural de vitamina C: el camu-camu (Myrciaria dubia).}

Resumen - La planta. El camu-camu (Myrciaria dubia) pertenece a la familia de las mirtáceas. Este arbusto crece naturalmente en las zonas anegadizas y pantanosas de la cuenca amazónica. Es actualmente cultivada en Perú y Brasil con rendimientos comprendidos entre (12 y 30) $\mathrm{t} \times \mathrm{ha}^{-1}$ por año. El fruto. De color rosado a violeta y de $(1 \mathrm{a} 3) \mathrm{cm}$ de diámetro, la baya de camu-camu tiene un contenido en vitamina $C$ extremamente elevado. Comprendido entre (850 a 5000) $\mathrm{mg} \times 100 \mathrm{~g}^{-1}$, su concentración es sin igual entre los frutos comestibles. El mercado. La demanda internacional del camu-camu ha aumentado considerablemente estos últimos años. El fruto es esencialmente utilizado como fuente natural de vitamina C y para la formulación de alimentos dietéticos. Sin embargo, la producción no logra cubrir su demanda. Conclusión. Entre los frutos secundarios amazónicos, el camu-camu presenta un potencial económico considerable. El estudio de procesos de transformación del fruto que respeten su calidad nutricional es indispensable.

Amazonia / Brasil / Perú / Myrciaria dubia / taxonomía / botánica / distribución geográfica / cultivo / composición química / acido ascorbico / mercados / procesamiento

To access this journal online: www.edpsciences.org 